\title{
Efektivitas Model Pembelajaran Conceptual Understanding Procedures Terhadap Peningkatan Penguasaan Konsep dan Keterampilan Proses Sains Siswa SMA Pada Materi Elastisitas dan Hukum Hooke
}

\author{
Fuad Sulistio ${ }^{\text {a, }}{ }^{*}$, Abdul Hakim a, ${ }^{\text {, }}$, Shelly Efwinda ${ }^{\text {a, } 3}$ \\ ${ }^{a}$ Universitas Mulawarman, Jalan Muara Pahu Kampus Gn. Kelua, Samarinda 75123 \\ ${ }^{1}$ fuadsulistio10@gmail.com*
}

\begin{abstract}
ABSTRAK
Penelitian ini bertujuan untuk mengetahui efektivitas model pembelajaran Conceptual Understanding Procedures (CUPs) terhadap peningkatan penguasaan konsep dan keterampilan proses sains siswa SMA pada materi elastisitas dan hukum Hooke. Populasi pada penelitian ini adalah seluruh siswa kelas XI SMA Negeri 9 Samarinda tahun ajaran 2019/2020. Sampel penelitian ini adalah siswa kelas XI MIPA 1 dan XI MIPA 3 yang masing-masing berjumlah 33 orang yang dipilih menggunakan teknik purposive sampling dengan desain penelitian static-group pre-test post-test design. Data dikumpulkan dengan menggunakan teknik tes berupa soal pilihan ganda penguasaan konsep dan keterampilan proses sains dan teknik non-tes berupa lembar observasi siswa. Hasil analisis data dengan menggunakan uji t independen berbantuan SPSS menunjukkan terdapat perbedaan yang signifikan pada peningkatan penguasaan konsep dan keterampilan proses sains siswa antara kelas eksperimen dan kontrol dengan perolehan p-value 0,040. Penerapan model CUPs dapat meningkatkan penguasaan konsep siswa dengan tingkat efektifitas sedang untuk tingkat kognitif C3 mengaplikasikan dengan nilai effect size 0,46 dan C4 menganalisis dengan nilai effect size 0,52, serta dapat meningkatkan keterampilan proses sains siswa pada indikator mengidentifikasi variabel dan mengolah data dengan tingkat efektifitas kecil dan pada indikator menyajikan data, merumuskan hipotesis, merancang penelitian dan melaksanakan eksperimen dengan tingkat efektifitas sedang.
\end{abstract}

Kata kunci : Conceptual Understanding Procedures, Penguasaan Konsep, Keterampilan Proses Sains

\begin{abstract}
This research aims to determine the effectiveness of the Conceptual Understanding Procedure learning model on improving the mastery of concepts and science process skills in high school students on the material elasticity and Hooke's law. The population in this study were all students of class XI of SMA Negeri 9 Samarinda in the academic year 2019/2020. The sample of this study was 33 students in grade XI MIPA 1 and XI MIPA 3, each selected using a purposive sampling technique with a static-group pre-test post-test design. The data were collected using a test technique in the form of multiple choice questions of concept mastery and science process skills and non-test techniques in the form of student observation sheets. The results of data analysis using the spss-assisted independent $t$ test showed that there were significant differences in the improvement of students' mastery of concepts and science process skills between the experiment and control classes with the acquisition of a p-value of 0.040. The application of the CUPs model can improve students mastery of concepts with a moderate level of effectiveness for the cognitive level, C3 applies with an effect size value of 0.46 and C4 analyzes with an effect size value of 0.52, and can improve students' science process skills on indicators of identifying variables and processing data with the level of effectiveness is small and the indicators present data, formulate hypotheses, design research and carry out experiments with moderate effectiveness levels.
\end{abstract}

Keyword: Conceptual Understanding Procedures, Concept Mastery, Science Process Skills

\section{PENDAHULUAN}

Berdasarkan Permendikbud Nomor 21 Tahun 2016, setiap siswa tingkat pendidikan menengah (kelas X-XII) diharapkan memiliki kompetensi untuk dapat merumuskan permasalahan yang berkaitan dengan fenomena fisika benda, merumuskan hipotesis, mendesain dan melaksanakan eksperimen, melakukan pengukuran secara teliti, mencatat dan menyajikan hasil dalam bentuk tabel dan grafik, menyimpulkan, serta melaporkan hasil serta melaporkan hasilnya secara lisan maupun tertulis (Permendikbud, 2016). 
Kurikulum 2013 merupakan sebuah kurikulum yang mengutamakan pemahaman, skill, dan pendidikan berkarakter. Siswa dituntut untuk paham atas materi, aktif dalam berdiskusi dan presentasi serta memiliki sopan santun juga disiplin yang tinggi. Kurikulum 2013 menerapkan pendekatan saintifik yang mengacu pada penemuan konsep dasar yang melandasi penerapan model pembelajran dengan menanamkan sikap ilmiah pada diri siswa dimana menyentuh pada tiga ranah yaitu sikap, pengetahuan, dan keterampilan yang sesuai dengan penilaian dalam kurikulum 2013. Proses pembelajaran pada hakikatnya berguna untuk mengembangkan keterampilan, aktivitas, dan kreativitas siswa melalui berbagai interaksi dan pengalaman belajar (Sudarmin, 2015).

Penguasaan proses dalam pembelajaran sains memerlukan sikap ilmiah yang tercakup dalam satu keterkaitan disebut keterampilan proses sains. Keterampilan proses sains merupakan keterampilan yang dapat mengaktifan, mengembangkan rasa ingin tahu, tanggung jawab, belajar mandiri, membantu siswa dalam melakukan penelitian, dan kemampuan proses lainnya. Siswa harus mengembangkan pengetahuan yang dimilikinya sehingga memunculkan penguasaan konsep yang mendalam. Pengaplikasian keterampilan proses sains dalam pembelajaran akan memperoleh hasil belajar yang optimal (Damayanti dan Ria, 2013).

Pembelajaran yang efektif merupakan hubungan yang cocok antara siswa dan lingkungan kelas (Yang dan Huang, 2015). Gunawan, dkk (2014) menyatakan bahwa beberapa konsep fisika termasuk konsep abstrak. Hal ini yang membuat siswa kurang aktif dalam berkomunikasi di kelas dan kreativitas fisika siswa rendah. Pembelajaran pada siswa juga memerlukan suatu pekerjaan dalam kelompok sehingga dapat belajar dengan baik (Chen et al, 2016). Menurut Sugiana, dkk (2016) bahwa siswa selalu memiliki gaya pembelajaran yang berbeda-beda serta penilaian berbeda mengenai pembelajaran yang sedang berlangsung. Pemilihan model pembelajaran yang tepat sangat dibutuhkan dalam pembelajaran IPA, sehingga siswa dapat memahami konsep serta mengembangkan keterampilan proses sains.

Perancangan pembelajaran yang inovatif dengan menggunakan strategi yang efektif terhadap peningkatan hasil belajar siswa juga perlu dilakuan (Dwi dkk, 2013). Pembelajaran fisika dengan menggunakan model pembelajaran yang lebih bervariasi serta proses pembelajaran yang berpusat pada siswa dapat menjadikan siswa berperan aktif dalam proses pembelajarannya, juga dapat membuat keterampilan proses sains dan hasil belajar fisika siswa menjadi lebih meningkat. Model pembelajaran yang dapat digunakan untuk meningkatkan keterampilan proses sains dan hasil belajar fisika siswa dalam proses pembelajaran adalah model pembelajaran Conceptual Understanding Procedures (CUPs).

Model pembelajaran CUPs adalah suatu model pembelajaran dimana pada siswa ditanamkan bagaimana membuat kesimpulan atas materi yang dipelajari. Melalui model ini diharapkan siswa mampu meningkatkan keterampilan proses sains, yaitu mampu melakukan pengamatan, menafsirkan pengamatan, meramalkan, menggunakan alat dan bahan, menerapkan konsep, merencanakan penelitian, berkomunikasi dan mengajukan pertanyaan. McKittrick dan Mulhall (2002) dalam Hikmah dkk (2015) menyatakan bahwa CUPs adalah sebuah prosedur yang terstruktur dan dapat menanamkan makna pada diri siswa sehingga dapat menanamkan makna pada diri siswa sehingga dapat membangun konsepkonsep yang dapat diterima secara ilmiah.

\section{METODE}

Jenis penelitian yang digunakan adalah penelitian kuantitatif yang menerapkan penelitian kuasi eksperimen (quasi experimental research). Desain penelitian yang digunakan yaitu tipe rancangan pemasangan subjek melalui tes awal dan tes akhir dengan kelompok kontrol (The Matching Only Pretest-Posttest Control Group Design) yang digambarkan oleh Freankel, Wallen, dan Hyun (2012: 271) seperti Tabel 1. 
Tabel 1. Desain penelitian pretest-posttest control group

\begin{tabular}{llccc}
\hline \multicolumn{1}{c}{ Sampel } & Kondisi Awal & Perlakuan & Kondisi Akhir \\
\cline { 2 - 5 } & \multicolumn{1}{c}{ Kelas Eksperimen } & $\mathrm{O}$ & $\mathrm{X}$ & $\mathrm{O}$ \\
\hline \multicolumn{1}{c}{ Kelas Kontrol } & $\mathrm{O}$ & $\mathrm{C}$ & $\mathrm{O}$ \\
\hline Keterangan $:$ & & $\mathrm{C}$ & : Pembelajaran Konvensional \\
$\mathrm{O}$ & : Pre-test dan Post-test & & &
\end{tabular}

(Fraenkel, Wallen, \& Hyun, 2012)

Berdasarkan tabel 1 dapat diketahui bahwa pada kelas eksperimen akan diberikan model pembelajaran CUPs dengan langkah-langkah sebagai berikut. 1) Siswa bekerja secara individu mengerjakan lembar kerja individu; 2) Siswa bekerja secara berkelompok melakukan kegiatan eksperimen secara berkelompok dan membuat laporan hasil eksperimen sesuai dengan lembar kerja; 3) Siswa berdiskusi dalam kelas mempresentasikan hasil kerja kelompok agar ditemukannya konsep yang sama berdasarkan permasalahan yang dibahas. Sebelum memberikan pembelajaran pada kedua kelas, dilakukan terlebih dahulu pre-test untuk mengetahui kemampuan awal siswa, kemudian diberikan perlakuan berupa penerapan model pembelajaran CUPs dan diakhiri dengan post-test.

Penelitian dilaksanakan mulai bulan agustus 2019 tahun ajaran 2019/2020 yang dilakukan sebanyak 6 pertemuan terdiri dari 2 pertemuan untuk memberikan pre-test, post-test dan 4 pertemuan perlakuan model pembelajaran CUPS pada kelas eksperimen dan model konvensional pada kelas kontrol. Penelitian ini bertempat di SMA Negeri 9 Samarinda, Kota Samarinda, Kalimantan Timur. Sampel penelitian ini yaitu kelas XI MIPA 1 dan XI MIPA 3 berjumlah 66 siswa. Teknik pengambilan sampel dalam penelitian ini dengan menggunakan teknik Purposive Sampling. Untuk pengumpulan data pada penelitian ini menggunakan teknik observasi dengan lembar observasi penskoran keterampilan proses sains dengan skor mulai dari skala 1 sampai dengan 4 dan teknik tes berupa tes formatif berbentuk pertanyaan pilihan ganda dengan 5 opsi pilihan jawaban dengan jumlah 30 soal pertanyaan penguasaan konsep dengan komposisi 18 soal diantaranya berdasarkan indikator keterampilan proses sains.

Data yang diperoleh pada penelitian ini yaitu nilai dari lembar observasi yang dirata-ratakan dan nilai dari pre-test dan post-test yang akan di uji dengan beberapa uji tes. Teknik analisis data yang digunakan pada penelitian ini adalah uji normalitas Shapiro-Wilk karena sampel tidak lebih dari 50. Jika data tidak berdistribusi normal, maka digunakan uji altenatif yaitu uji Wilcoxon Signed Rank Test. Uji selanjutnya yaitu uji homogenitas untuk memperoleh asumsi bahwa sampel penelitian berawal dari kondisi yang sama atau homogen. Ketiga uji tersebut merupakan uji syarat dari uji t independen dengan menggunakan data pre-test dan post-test untuk membuktikan hipotesis yang di buat bernilai benar atau salah. Hipotesis yang dibuat yaitu model pembelajaran Conceptual Understanding Procedures (CUPs) terdapat perbedaan yang signifikan dalam meningkatkan penguasaan konsep dan keterampilan proses sains siswa dibandingkan dengan model pembelajaran konvensional. Untuk menguji peningkatan penguasaan konsep dan keterampilan proses sains digunakan uji Normalized Gain (N-Gain) dan untuk mengukur besarnya efektivitas model pembelajaran digunakan uji Effect Size.

\section{HASIL DAN PEMBAHASAN}

Penelitian ini dilaksanakan secara kuantitatif pada kelas XI MIPA 1 dan XI MIPA 3 di SMA Negeri 9 Samarinda. Pada setiap data hasil penelitian ini di uji dengan menggunakan bantuan aplikasi SPSS 24.0 for Windows dan aplikasi Microsoft Office Excel 2013. Berdasarkan uji normalitas dan uji homogenitas yang dilakukan terhadap hasil data pre-test dari 30 soal yang diujikan berdasarkan 
penguasaan konsep dan keterampilan proses sains seperti ditunjukkan pada Tabel 2 dan Tabel 3 pada kelas XI MIPA 1 dan XI MIPA 3 yang masing-masing berjumlah 33 peserta didik diperoleh bahwa kedua kelas tersebut berdistribusi normal (sig. > 0,05) dan memiliki tingkat kemampuan yang homogen (Asymp Sig. > 0,05). Peneliti menerapkan pembelajaran yang berbeda pada kedua kelas tersebut. Pada kelas eksperimen yaitu kelas XI MIPA 1 diterapkan pembelajaran Conceptual Understanding Procedures sedangkan pada kelas kontrol yaitu kelas XI MIPA 3 diterapkan pembelajaran konvensional.

Tabel 2. Hasil Uji Normalitas Data Pre-Test dengan SPSS

\begin{tabular}{ccccc}
\hline \multicolumn{5}{c}{ Test of Normality Shapiro-Wilk } \\
\hline \multirow{2}{*}{ Pre-Test } & Kelompok & Statistic & Df & Sig. \\
\cline { 2 - 5 } & Eksperimen & 0,970 & 33 & 0,473 \\
\cline { 2 - 3 } & Kontrol & 0,946 & 33 & 0,102 \\
\hline
\end{tabular}

Tabel 3. Hasil Uji Homogenitas Data Pre-Test dengan SPSS

\begin{tabular}{cccc}
\hline \multicolumn{4}{c}{ Test of Homogeneity of Variances } \\
\hline Pre-Test & & & \\
\hline Levene Statistic & $d f 1$ & $d f 2$ & Sig. \\
\hline 2,223 & 1 & 64 & 0,141 \\
\hline
\end{tabular}

Hasil dari observasi selama empat pertemuan tersebut kemudian di analisis dengan mencari nilai rata-rata yang diperoleh seluruh peserta didik kelas eksperimen yang ditunjukkan pada Tabel 4.

Tabel 4. Data Persentase Lembar Observasi KPS Setiap Pertemuan

\begin{tabular}{ccccc}
\hline \multirow{2}{*}{ No. } & \multicolumn{4}{c}{ Nilai $(\%)$} \\
\cline { 2 - 5 } & Pert.1 & Pert.2 & Pert.3 & Pert.4 \\
\hline 1. & 52,27 & 61,36 & 59,09 & 100,0 \\
2. & 31,82 & 41,67 & 43,94 & 72,73 \\
3. & 44,70 & 38,64 & 56,82 & 87,88 \\
4. & 61,36 & 68,18 & - & 96,97 \\
5. & 50,00 & 69,70 & 76,52 & 92,42 \\
6. & 25,00 & 26,52 & 39,39 & 75,00 \\
7. & 34,85 & 25,00 & 55,30 & 85,61 \\
8. & 25,00 & 25,00 & 36,36 & 77,27 \\
9. & 31,82 & 25,00 & 55,30 & 84,85 \\
\hline Rata- & \multirow{2}{*}{39,65} & 42,34 & 52,84 & 85,86 \\
rata & & &
\end{tabular}

Catatan :1) Memprediksi; 2) Mengajukan hipotesis; 3) Merencanakan percobaan; 4) Menggunakan alat/bahan; 5) Melakukan percobaan; 6) Mengobservasi; 7) Menerapkan konsep/prinsip; Menginterpretasi; 9) Mengkomunikasikan.

Pertemuan 1 : Modulus Young

Pertemuan 2 : Hukum Hooke

Pertemuan 3 : Energi Potensial Pegas

Pertemuan 4 : Susunan Pegas

Gambar 1. Informasi mengenai Lembar Observasi KPS

Pada Tabel 4 dapat dilihat pada pertemuan pertama mengenai modulus elastisitas, siswa masih baru mencoba untuk menyesuaikan model pembelajaran CUPs sehingga didapatkan rata-rata pada pertemuan pertama masih rendah. Pada pertemuan kedua mengenai hukum Hooke terlihat peningkatan yang baik dari sebelumnya karena siswa sudah mulai menyesuaikan model pembelajaran CUPs dan sudah 
mengenal beberapa alat-alat praktikum yang dilaksanakan untuk menyelesaikan LKPD yang diberikan, namun masih dalam kategori rendah. Pada pertemuan ketiga mengenai energi potensial pegas terlihat peningkatan yang baik dari sebelumnya karena pada pertemuan ketiga ini siswa melakukan praktikum secara virtual menggunakan aplikasi PhET sehingga diperoleh data lembar observasi yang cukup baik namun masih dalam kategori rendah. Pada pertemuan keempat mengenai susunan pegas terlihat peningkatan yang sangat signifikan, karena materi susunan pegas ini merupakan penerapan dari konsepkonsep sebelumnya sehingga siswa dapat melakukan praktikum dan menyelesaikan LKPD dengan baik dan benar.

Pada hasil uji normalitas yang ditunjukkan pada Tabel 5 diperoleh bahwa data post-test peserta didik kelas eksperimen dan kelas kontrol terdistribusi normal (sig. > 0,05). Namun pada hasil uji homogenitas yang ditunjukkan pada Tabel 6 diperoleh bahwa data post-test peserta didik kelas eksperimen dan kelas kontrol tidak homogen $(0,007<0,05)$. Hal ini dikarenakan terdapat perbedaan perlakuan antara kelas eksperimen dan kelas kontrol.

Tabel 5. Hasil Uji Normalitas Data Post-Test dengan SPSS

\begin{tabular}{ccccc}
\hline \multicolumn{5}{c}{ Test of Normality Shapiro-Wilk } \\
\hline & Kelompok & Statistic & Df & Sig. \\
\hline \multirow{2}{*}{ Post-Test } & Eksperimen & 0,973 & 33 & 0,571 \\
& Kontrol & 0,970 & 33 & 0,470 \\
\hline
\end{tabular}

Tabel 6. Hasil Uji Homogenitas Data Post-Test dengan SPSS

\begin{tabular}{cccc}
\hline \multicolumn{4}{c}{ Test of Homogeneity of Variances } \\
\hline \multicolumn{4}{c}{ Post-Test } \\
\hline Levene Statistic & $d f 1$ & $d f 2$ & Sig. \\
\hline 7,868 & 1 & 64 & 0,007 \\
\hline
\end{tabular}

Pre-test dan post-test dilakukan pada kelas eksperimen dan kontrol dengan jumlah sampel tiap kelas sebanyak 33 peserta didik dengan menggunakan instrumen tes yang sama. Hasil data tersebut disajikan pada Tabel 7.

Tabel 7. Hasil Statistik Deskriptif Pre-Test dan Post-Test Kelas Eksperimen dan Kontrol

\begin{tabular}{ccccc}
\hline \multirow{2}{*}{ Kelas } & \multicolumn{2}{c}{ Eksperimen } & \multicolumn{2}{c}{ Kontrol } \\
\cline { 2 - 5 } & Pre & Post & Pre & Post \\
N & 33 & 33 & 33 & 33 \\
Min & 16,7 & 40,0 & 20,0 & 23,3 \\
Max & 46,7 & 73,3 & 53,3 & 76,7 \\
Mean & 32,9 & 55,2 & 37,9 & 52,7 \\
Std. Deviation & 7,39 & 8,12 & 9,15 & 13,14 \\
\hline
\end{tabular}

Hasil statistik deskriptif dari data pre-test dan post-test ditunjukkan pada Tabel 7 yang menunjukkan bahwa kelas eksperimen dan kelas kontrol mengalami peningkatan rata-rata keterampilan proses sains dan pengguasaan konsep yang berbeda yaitu pada kelas eksperimen yang awalnya pada pre-test memiliki rata-rata 32,9 dengan deviasi standar 7,39 meningkat menjadi 55,2 dengan deviasi standar 8,12 sesuai dengan nilai rata-rata post-test. Pada kelas kontrol yang awalnya pada pre-test memiliki rata-rata 37,9 dengan deviasi standar 9,15 meningkat juga menjadi 52,7 dengan deviasi standar 13,14 sesuai dengan nilai rata-rata post-test.

$\mathrm{N}$-Gain memberikan gambaran umum mengenai peningkatan nilai pada penguasaan konsep antara pre-test dan post-test pada kelas eksperimen dan kontrol. Peningkatan tersebut pada kelas eksperimen dan kontrol disajikan pada Tabel 8. 
Tabel 8. Hasil Analisis N-Gain Kelas Eksperimen dan Kontrol pada Penguasaan Konsep.

\begin{tabular}{ccccc}
\hline \multirow{2}{*}{ Kelas } & \multicolumn{2}{c}{ Eksperimen } & \multicolumn{2}{c}{ Kontrol } \\
\cline { 2 - 6 } & Pre & Post & Pre & Post \\
\hline Mean & 32,93 & 55,24 & 37,88 & 52,73 \\
SD & 7,39 & 8,12 & 9,15 & 13,14 \\
N-Gain & & 0,32 & & 0,22 \\
SD & \multicolumn{2}{c}{0,15} & \multicolumn{2}{c}{0,23} \\
\hline Kategori & \multicolumn{2}{c}{ Sedang } & Rendah \\
\hline
\end{tabular}

Bila digambarkan dalam bentuk grafik, nilai penguasaan konsep peserta didik dan nilai N-Gain yang diperoleh kedua kelas disajikan pada Gambar 2.

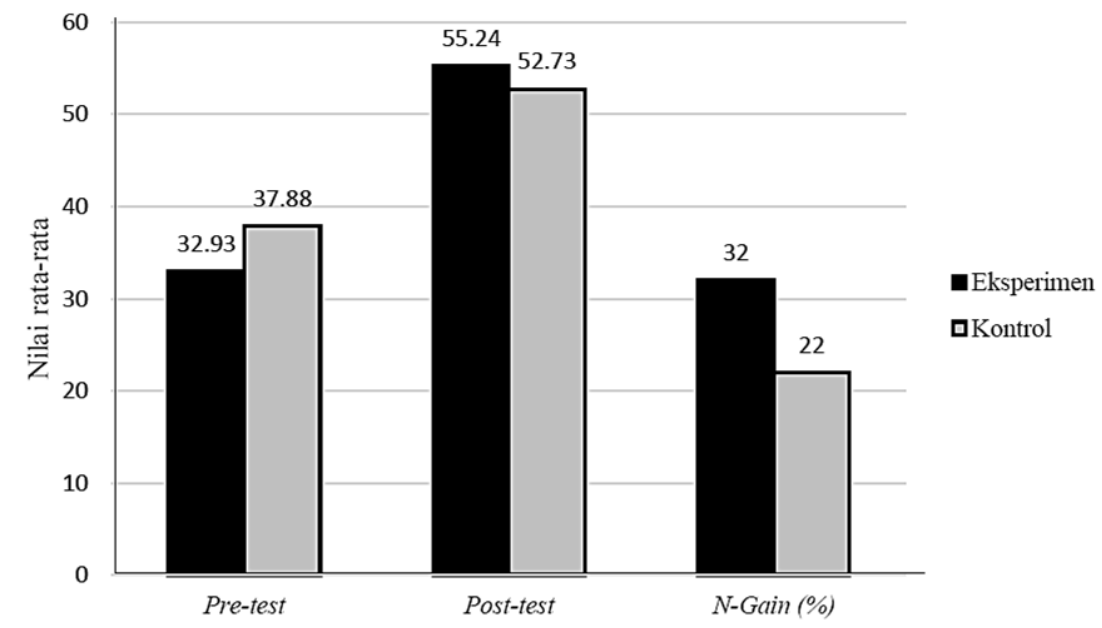

Gambar 2. Grafik Nilai Rata-Rata Pre-Test dan Post-Test Secara Umum dan Persentase N-Gain

Peningkatan penguasaan konsep dan keterampilan proses sains dianalisis dengan uji $\mathrm{N}$-Gain dan ditunjukkan pada Tabel 8 pada kelas eksperimen yang diterapkan model pembelajaran CUPs diperoleh $\mathrm{N}$-Gain sebesar 0,32 dimana nilai tersebut masuk dalam kriteria sedang dan pada kelas kontrol yang diterapkan model konvensional diperoleh $\mathrm{N}$-Gain sebesar 0,22 dimana nilai tersebut masuk dalam kriteria rendah. Hal ini menunjukkan bahwa penerapan model pembelajaran CUPs dapat meningkatkan keterampilan proses sains dan pengguasaan konsep sebesar 32\% dengan kategori peningkatannya adalah sedang sedangkan model konvensional hanya dapat meningkatkan keterampilan proses sains dan pengguasaan konsep sebesar 22\%. Pada kelas eksperimen dan kelas kontrol terdapat perbedaan $\mathrm{N}$-Gain yang cukup signifikan.

Peningkatan nilai pada level kognitif peserta didik diukur berdasarkan nilai N-Gain tiap level kognitif kelas eksperimen dan kelas kontrol yang diperoleh dari hasil pre-test dan post-test siswa. Nilai N-Gain pada setiap level kognitif disajikan pada Tabel 9.

Tabel 9. Hasil Analisis N-Gain Kelas Eksperimen dan Kontrol Tiap Level Kognitif.

\begin{tabular}{ccccc}
\hline \multicolumn{2}{c}{ Level Kognitif } & C2 & C3 & C4 \\
\hline \multirow{4}{*}{ Eksperimen } & Pre & 40,2 & 30,5 & 29,9 \\
& Post & 54,5 & 55,8 & 54,9 \\
& N-Gain & 0,19 & 0,35 & 0,33 \\
\hline \multirow{3}{*}{ Kontrol } & Pre & 42,8 & 38,5 & 31,8 \\
& Post & 56,4 & 53,2 & 48,1 \\
& N-Gain & 0,19 & 0,21 & 0,18 \\
\hline
\end{tabular}


Jika digambarkan dalam bentuk grafik, perolehan persentase nilai N-Gain tiap level kognitif disajikan pada Gambar 3.

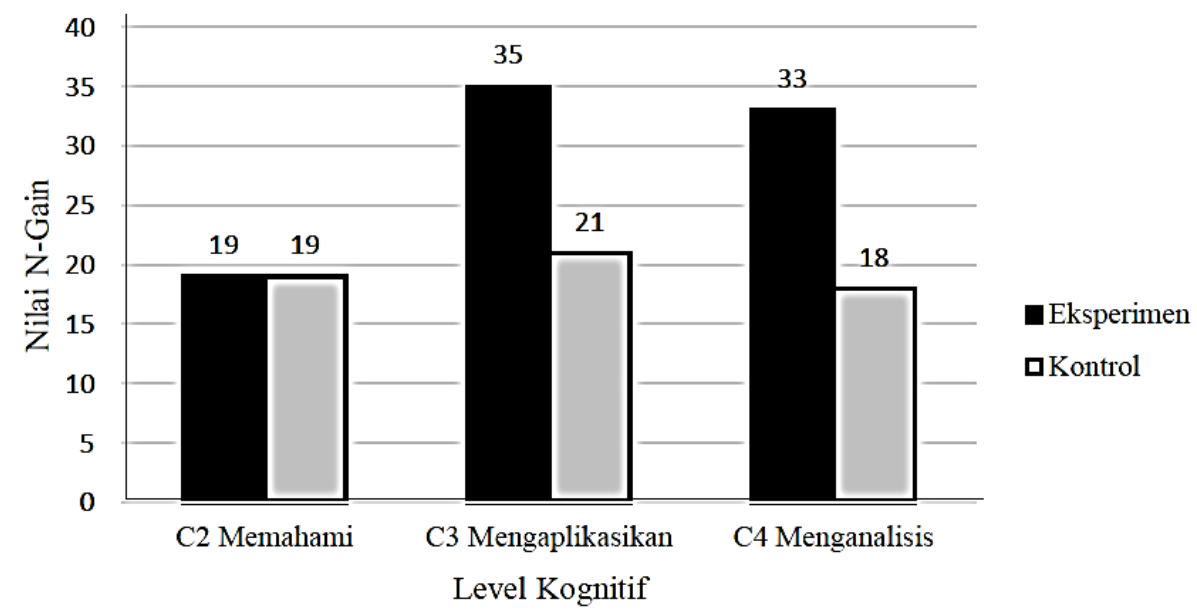

Gambar 3. Grafik nilai persentase N-Gain tiap level kognitif

Berdasarkan Gambar 3 terdapat perbedaan nilai $N$-Gain antara kelas eksperimen dan kelas kontrol. Nilai $N$-Gain dari kelas eksperimen dan kelas kontrol berdasarkan kategori Hake (1999) untuk level kognitif C2 yaitu memahami diperoleh kategori rendah. Untuk level kognitif C3 yaitu mengaplikasikan diperoleh kategori sedang pada kelas eksperimen dan kategori rendah pada kelas kontrol. Untuk level kognitif $\mathrm{C} 4$ yaitu menganalisis diperoleh kategori sedang pada kelas eksperimen dan kategori rendah pada kelas kontrol.

Peningkatan indikator keterampilan proses sains peserta didik diukur berdasarkan nilai $\mathrm{N}$-Gain tiap indikator keterampilan proses sains kelas eksperimen dan kelas kontrol dari 18 soal yang diujikan pada pre-test dan post-test. Nilai $\mathrm{N}$-Gain pada setiap indikator keterampilan proses sains disajikan pada Tabel 10.

Tabel 10. Hasil Analisis N-Gain Kelas Eksperimen dan Kontrol Tiap Indikator KPS.

\begin{tabular}{lcc}
\hline \multirow{2}{*}{ Indikator KPS } & \multicolumn{2}{c}{ N-Gain } \\
\cline { 2 - 3 } & \multicolumn{2}{c}{ Rata-rata } \\
\cline { 2 - 3 } 1. Mengidentifikasi variabel & 0,21 & 0,15 \\
2. Tabulasi data & 0,04 & 0,21 \\
3. Menyajikan data & 0,32 & 0,00 \\
4. Merumuskan hipotesis & 0,70 & 0,46 \\
5. Menghubungkan antar & 0,02 & 0,36 \\
variabel & 0,06 & 0,23 \\
6. Menganalisa penelitian & 0,23 & 0,15 \\
7. Mengolah data & 0,57 & 0,26 \\
8. Merancang penelitian & 0,62 & 0,44 \\
9. Melakasanakan & & 0,25 \\
\hline eksperimen & 0,31 & \\
\hline Rata-rata & & \\
\hline
\end{tabular}

Jika digambarkan dalam bentuk grafik, perolehan persentase nilai $\mathrm{N}$-Gain tiap indikator keterampilan proses sains (KPS) disajikan pada Gambar 4. 


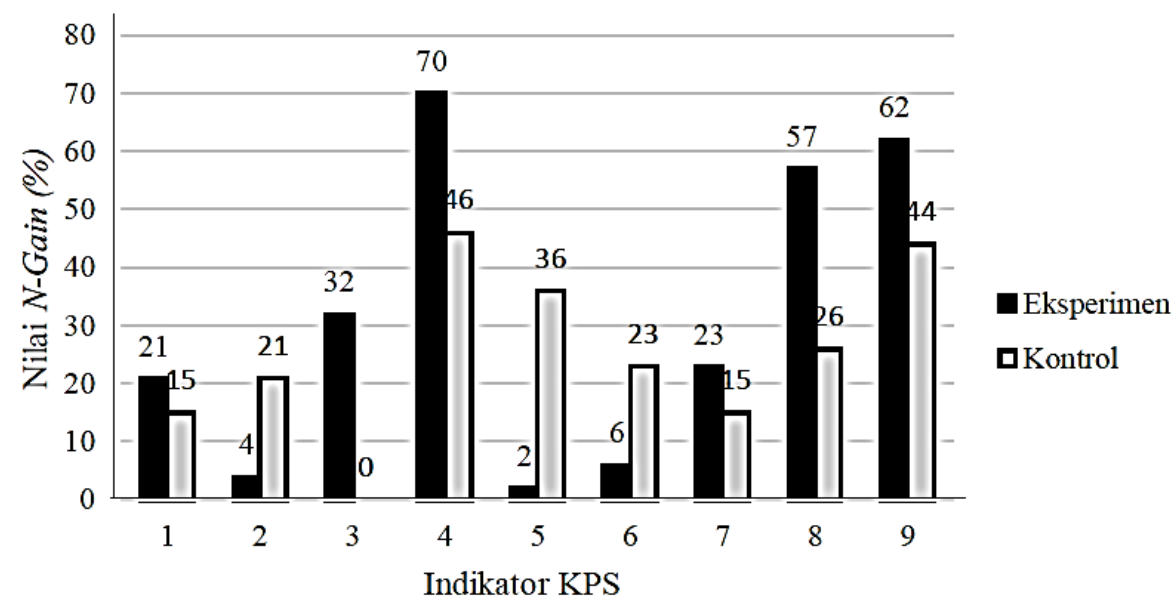

Gambar 4. Grafik Nilai N-Gain Tiap Indikator Keterampilan Proses Sains

Berdasarkan Gambar 4 menunjukan bahwa pada indikator 1 yaitu mengidentifikasi variabel diperoleh $\mathrm{N}$-Gain dalam kategori rendah pada kelas eksperimen dan kelas kontrol. Pada indikator 2 yaitu tabulasi data diperoleh $\mathrm{N}$-Gain dalam kategori rendah untuk kedua kelas. Pada indikator 3 yaitu menyajikan data diperoleh $\mathrm{N}$-Gain dalam kategori sedang untuk kelas eksperimen dan tidak memiliki peningkatan untuk kelas kontrol. Pada indikator 4 yaitu merumuskan hipotesis diperoleh $\mathrm{N}$-Gain dalam kategori sedang untuk kedua kelas. Pada indikator 5 yaitu menghubungkan antar variabel diperoleh $\mathrm{N}$ Gain dalam kategori rendah untuk kelas eksperimen dan kategori sedang untuk kelas kontrol. Pada indikator 6 yaitu menganalisa penelitian diperoleh $N$-Gain dalam kategori rendah untuk kedua kelas. Pada indikator 7 yaitu mengolah data diperoleh $N$-Gain dalam kategori rendah untuk kedua kelas. Pada indikator 8 yaitu merancang penelitian diperoleh $\mathrm{N}$-Gain dalam kategori sedang untuk kelas eksperimen dan kategori rendah untuk kelas kontrol. Pada indikator 9 yaitu melaksanakan eksperimen diperoleh $\mathrm{N}$ Gain dalam kategori sedang untuk kedua kelas. Perbedaan rata-rata $\mathrm{N}$-Gain tiap indikator menunjukkan perbedaan peningkatan yang dialami peserta didik dalam peningkatan keterampilan proses sains tiap indikatornya pada materi elastisitas dan hukum Hooke.

Perbedaan rerata $\mathrm{N}$-Gain tiap indikator penguasaan konsep pada kelas eksperimen dan kelas kontrol akan dianalisis menggunakan uji t-independen. Uji tersebut bertujuan untuk melihat kemampuan peserta didik tiap indikator setelah menerima pembelajaran serta untuk mengetahui ada tidaknya perbedaan secara signifikan tiap indikator penguasaan konsep peserta didik pada kelas eksperimen dan kontrol. Sebelum melakukan uji t-independen diperlukan uji normalitas terlebih dahulu dari data $N$-Gain yang di peroleh dari kelas eksperimen dan kontrol. Uji normalitas yang digunakan adalah uji normalitas Shapiro-Wilk, karena jumlah sampel kurang dari 50 orang. Analisis uji normalitas data N-Gain terhadap kelas eksperimen dan kelas kontrol menggunakan bantuan aplikasi SPSS 24.0 for Windows. Hasil data tersebut disajikan pada Tabel 11.

Tabel 11. Hasil Uji Normalitas $N$-Gain tiap Level Kognitif pada Kelas Eksperimen dan Kontrol.

\begin{tabular}{ccccc}
\hline \multicolumn{5}{c}{ Test of Normality Shapiro-Wilk } \\
\hline \multirow{2}{*}{ N-Gain } & Kelompok & Statistic & Df & Sig. \\
& Eksperimen & 0,953 & 33 & 0,159 \\
& Kontrol & 0,970 & 33 & 0,490 \\
\hline
\end{tabular}

Berdasarkan Tabel 11 diperoleh nilai (Sig.) dalam uji Shapiro-Wilk untuk nilai $N$-Gain pada kelas eksperimen adalah 0,159 dan kelas kontrol 0,490. Karena nilai Sig. kedua kelas tersebut lebih besar dari 0,05 maka dapat dikatakan bahwa data yang digunakan dalam penelitian ini adalah berdistribusi normal. Dengan demikian persyaratan penggunaan uji-t independen untuk $\mathrm{N}$-Gain dapat dilakukan. 
Analisis uji-t independen untuk $N$-Gain terhadap kelas eksperimen dan kelas kontrol menggunakan bantuan aplikasi SPSS 24.0 for Windows. Hasil data tersebut disajikan pada Tabel 12.

Tabel 12. Hasil Uji-t Independen untuk Data $\mathbf{N}$-Gain Kelas Eksperimen dan Kontrol

\begin{tabular}{|c|c|c|c|c|c|c|c|}
\hline \multicolumn{8}{|c|}{ Independent Samples Test } \\
\hline \multicolumn{3}{|c|}{$\begin{array}{c}\text { Levene's Test for Equality of } \\
\text { Variances }\end{array}$} & \multicolumn{5}{|c|}{ t-test for Equality of Means } \\
\hline & $\mathrm{F}$ & Sig. & $t$ & $d f$ & $\begin{array}{l}\text { Sig. }(2- \\
\text { tailed })\end{array}$ & $\begin{array}{c}\text { Mean } \\
\text { Difference }\end{array}$ & $\begin{array}{l}\text { Std. Error } \\
\text { Difference }\end{array}$ \\
\hline $\begin{array}{l}\text { Equal } \\
\text { variances }\end{array}$ & 8,86 & 0,004 & 2,10 & 64 & 0,040 & 10,03 & 4,77 \\
\hline $\begin{array}{l}\text { assumed } \\
\text { Equal }\end{array}$ & & & & & & & \\
\hline $\begin{array}{l}\text { variances not } \\
\text { assumed }\end{array}$ & & & 2,10 & 54,08 & 0,040 & 10,03 & 4,77 \\
\hline
\end{tabular}

Berdasarkan Tabel 12 diketahui nilai Sig. (2-tailed) adalah sebesar 0,040 < 0,05, dengan demikian maka dapat disimpulkan model pembelajaran Conceptual Understanding Procedures (CUPs) lebih baik dalam meningkatkan penguasaan konsep dan keterampilan proses sains siswa secara signifikan dibandingkan dengan model pembelajaran konvensional.

Uji perbedaan tiap indikator penguasaan konsep di uji dengan bantuan software SPSS 24.0 for Windows. Perbedaan rerata $\mathrm{N}$-Gain tiap indikator penguasaan konsep pada kelas eksperimen dan kelas kontrol bertujuan untuk melihat kemampuan peserta didik tiap indikator setelah menerima pembelajaran serta untuk mengetahui ada tidaknya perbedaan secara signifikan tiap indikator penguasaan konsep peserta didik yang diperoleh dari nilai $\mathrm{N}$-Gain. Hasil analisis perbedaan rerata $\mathrm{N}$-Gain untuk tiap indikator penguasaan konsep disajikan pada Tabel 13.

Tabel 13. Hasil Uji Perbedaan Rerata N-Gain tiap Level Kognitif pada Kelas Eksperimen dan Kontrol.

\begin{tabular}{|c|c|c|c|c|c|c|}
\hline \multirow{2}{*}{ Level Kognitif } & \multicolumn{4}{|c|}{ Uji Normalitas } & \multicolumn{2}{|c|}{ Uji-T } \\
\hline & Eksperimen & SD & Kontrol & SD & Rata-rata & Makna \\
\hline $\begin{array}{l}\text { C2 } \\
\text { Memahami }\end{array}$ & $\begin{array}{c}\text { Tidak normal } \\
\text { (Sig. 0,028) }\end{array}$ & 0,31 & $\begin{array}{c}\text { Tidak normal } \\
\text { (Sig. 0,003) }\end{array}$ & 0,43 & $\begin{array}{c}\mathrm{Z}=-0,393 \\
\text { (Sig. 0,694) }\end{array}$ & $\begin{array}{c}\text { Tidak } \\
\text { berbeda } \\
\text { signifikan }\end{array}$ \\
\hline $\begin{array}{l}\text { C3 } \\
\text { Mengaplikasikan }\end{array}$ & $\begin{array}{c}\text { Normal } \\
\text { (Sig. 0,200) }\end{array}$ & 0,20 & $\begin{array}{c}\text { Normal } \\
\text { (Sig. 0,084) }\end{array}$ & 0,38 & $\begin{array}{c}\mathrm{Z}=1,723 \\
(\text { Sig. } 0,005)\end{array}$ & $\begin{array}{c}\text { Berbeda } \\
\text { signifikan }\end{array}$ \\
\hline $\begin{array}{l}\text { C4 } \\
\text { Menganalisis }\end{array}$ & $\begin{array}{c}\text { Normal } \\
\text { (Sig. 0,084) }\end{array}$ & 0,26 & $\begin{array}{c}\text { Normal } \\
(\text { Sig. } 0,080)\end{array}$ & 0,31 & $\begin{array}{c}\mathrm{Z}=0,985 \\
\text { (Sig. 0,287) }\end{array}$ & $\begin{array}{c}\text { Tidak } \\
\text { berbeda } \\
\text { signifikan }\end{array}$ \\
\hline
\end{tabular}

Peningkatan tiap indikator penguasaan konsep pada level kognitif C3 Mengaplikasikan antara kelas eksperimen dan kelas kontrol memiliki perbedaan yang signifikan ( $p$-value $<0,05$ ) sedangkan pada level kognitif C2 Memahami dan C4 Menganalisis antara kelas eksperimen dan kontrol tidak memiliki perbedaan yang signifikan ( $\mathrm{p}$-value $>0,05$ ).

Uji perbedaan tiap indikator keterampilan proses sains di uji dengan bantuan software SPSS 24.0 for Windows. Perbedaan rerata N-Gain tiap indikator keterampilan proses sain pada kelas eksperimen dan kelas kontrol bertujuan untuk melihat kemampuan peserta didik tiap indikator setelah menerima pembelajaran serta untuk mengetahui ada tidaknya perbedaan secara signifikan tiap indikator keterampilan proses sains peserta didik yang diperoleh dari nilai $N$-Gain.

Hasil analisis perbedaan rerata N-Gain untuk tiap indikator keterampilan proses sains (KPS) disajikan pada Tabel 14. 
Tabel 14. Hasil Uji Perbedaan Rerata N-Gain tiap Indikator KPS pada Kelas Eksperimen dan Kontrol.

\begin{tabular}{|c|c|c|c|c|c|c|c|}
\hline \multirow{2}{*}{\multicolumn{2}{|c|}{$\begin{array}{c}\text { Indikator } \\
\text { Keterampilan } \\
\text { Proses Sains }\end{array}$}} & \multicolumn{4}{|c|}{ Uji Normalitas } & \multicolumn{2}{|c|}{ Uji-T } \\
\hline & & Eksperimen & SD & Kontrol & SD & Rata-rata & Makna \\
\hline 1. & $\begin{array}{l}\text { Mengidentifi- } \\
\text { kasi variabel }\end{array}$ & $\begin{array}{l}\text { Tidak normal } \\
(\text { Sig. 0,000) }\end{array}$ & 0,36 & $\begin{array}{l}\text { Tidak normal } \\
\text { (Sig. 0,000) }\end{array}$ & 0,59 & $\begin{array}{c}\mathrm{Z}=-0,314 \\
\text { (Sig. 0,754) }\end{array}$ & $\begin{array}{c}\text { Tidak } \\
\text { berbeda } \\
\text { signifikan }\end{array}$ \\
\hline 2. & Tabulasi data & $\begin{array}{l}\text { Tidak normal } \\
\text { (Sig. 0,000) }\end{array}$ & 0,27 & $\begin{array}{l}\text { Tidak normal } \\
\text { (Sig. 0,000) }\end{array}$ & 0,63 & $\begin{array}{c}\mathrm{Z}=-1,116 \\
(\text { Sig. 0,264) }\end{array}$ & $\begin{array}{c}\text { Tidak } \\
\text { berbeda } \\
\text { signifikan }\end{array}$ \\
\hline & $\begin{array}{l}\text { Menyajikan } \\
\text { data }\end{array}$ & $\begin{array}{l}\text { Tidak normal } \\
\text { (Sig. 0,003) }\end{array}$ & 0,53 & $\begin{array}{l}\text { Tidak normal } \\
\text { (Sig. 0,002) }\end{array}$ & 0,79 & $\begin{array}{c}\mathrm{Z}=-1,219 \\
\text { (Sig. 0,223) }\end{array}$ & $\begin{array}{c}\text { Tidak } \\
\text { berbeda } \\
\text { signifikan }\end{array}$ \\
\hline & $\begin{array}{l}\text { Merumuskan } \\
\text { hipotesis }\end{array}$ & $\begin{array}{l}\text { Tidak normal } \\
(\text { Sig. 0,000) }\end{array}$ & 0,40 & $\begin{array}{l}\text { Tidak normal } \\
\text { (Sig. 0,000) }\end{array}$ & 0,75 & $\begin{array}{c}\mathrm{Z}=-0,214 \\
\text { (Sig. 0,831) }\end{array}$ & $\begin{array}{c}\text { Tidak } \\
\text { berbeda } \\
\text { signifikan }\end{array}$ \\
\hline 5 . & $\begin{array}{l}\text { Menghubung- } \\
\text { kan antar } \\
\text { variabel }\end{array}$ & $\begin{array}{l}\text { Tidak normal } \\
\text { (Sig. 0,001) }\end{array}$ & 0,70 & $\begin{array}{l}\text { Tidak normal } \\
\text { (Sig. 0,000) }\end{array}$ & 0,32 & $\begin{array}{c}\mathrm{Z}=-1,858 \\
(\text { Sig. 0,063) }\end{array}$ & $\begin{array}{c}\text { Tidak } \\
\text { berbeda } \\
\text { signifikan }\end{array}$ \\
\hline 6. & $\begin{array}{l}\text { Menganalisa } \\
\text { penelitian }\end{array}$ & $\begin{array}{l}\text { Tidak normal } \\
(\text { Sig. 0,000) }\end{array}$ & 0,67 & $\begin{array}{l}\text { Tidak normal } \\
\text { (Sig. 0,000) }\end{array}$ & 0,48 & $\begin{array}{c}\mathrm{Z}=-2,018 \\
\text { (Sig. 0,044) }\end{array}$ & $\begin{array}{c}\text { Berbeda } \\
\text { signifikan }\end{array}$ \\
\hline 7. & Mengolah data & $\begin{array}{l}\text { Tidak normal } \\
\text { (Sig. 0,001) }\end{array}$ & 0,66 & $\begin{array}{l}\text { Tidak normal } \\
\text { (Sig. 0,000) }\end{array}$ & 0,64 & $\begin{array}{c}\mathrm{Z}=-0,652 \\
(\text { Sig. 0,520) }\end{array}$ & $\begin{array}{c}\text { Tidak } \\
\text { berbeda } \\
\text { signifikan }\end{array}$ \\
\hline & $\begin{array}{l}\text { Merancang } \\
\text { penelitian }\end{array}$ & $\begin{array}{l}\text { Tidak normal } \\
(\text { Sig. 0,000) }\end{array}$ & 0,43 & $\begin{array}{c}\text { Tidak normal } \\
\text { (Sig. 0,000) }\end{array}$ & 0,46 & $\begin{array}{c}\mathrm{Z}=-2,550 \\
(\text { Sig. 0,011) }\end{array}$ & $\begin{array}{l}\text { Berbeda } \\
\text { signifikan }\end{array}$ \\
\hline 9. & $\begin{array}{l}\text { Melaksanakan } \\
\text { eksperimen }\end{array}$ & $\begin{array}{l}\text { Tidak normal } \\
(\text { Sig. 0,000) }\end{array}$ & 0,34 & $\begin{array}{l}\text { Tidak normal } \\
\text { (Sig. 0,000) }\end{array}$ & 0,62 & $\begin{array}{c}\mathrm{Z}=-0,921 \\
(\text { Sig. 0,357) }\end{array}$ & $\begin{array}{c}\text { Tidak } \\
\text { berbeda } \\
\text { signifikan }\end{array}$ \\
\hline
\end{tabular}

Hasil uji normalitas yang ditampilkan pada Tabel 14 diatas menunjukkan bahwa semua data $\mathrm{N}$ Gain setiap indikator yang berdistribusi secara tidak normal sehingga uji beda yang digunakan adalah uji non parametrik yaitu uji Mann Whitney U Test. Peningkatan keterampilan proses sains pada indikator menganalisa penelitian dan merancang penelitian antara kelas eksperimen dan kelas kontrol memiliki perbedaan yang signifikan ( $p$-value $<0,05$ ) sedangkan pada indikator mengidentifikasi variabel, tabulasi data, menyajikan data, merumuskan hipotesis, menghubungkan antar variabel, mengolah data, dan melaksanakan eksperimen antara kelas eksperimen dan kontrol tidak memiliki perbedaan yang signifikan ( $p$-value $>0,05$ ). Secara keseluruhan terlihat bahwa model pembelajaran CUPs tidak memberikan perbedaan yang signifikan terhadap model pembelajaran konvensional untuk meningkatkan keterampilan proses sains (KPS).

Uji effect size digunakan untuk mengetahui efektivitas model CUPs terhadap peningkatan penguasaan konsep. Hasil Uji effect size disajikan pada Tabel 15.

Tabel 15. Hasil Uji Effect Size N-Gain Kelas Eksperimen dan Kelas Kontrol Terhadap Penguasaan Konsep.

\begin{tabular}{lcccccc}
\hline \multirow{2}{*}{ Level kognitif } & \multicolumn{2}{c}{ Eksperimen } & Kontrol & Effect Size & \multirow{2}{*}{ Kategori } \\
\cline { 2 - 5 } & $\boldsymbol{N}$-Gain & SD & $\boldsymbol{N}$-Gain & SD & $($ d) & \\
\hline C2 Memahami & 0,19 & 0,31 & 0,19 & 0,43 & 0 & Tidak ada \\
C3 Mengaplikasikan & 0,35 & 0,20 & 0,21 & 0,38 & 0,46 & Sedang \\
C4 Menganalisis & 0,33 & 0,26 & 0,18 & 0,31 & 0,52 & Sedang \\
\hline
\end{tabular}


Berdasarkan Tabel 15 diperoleh bahwa hasil uji effect size $N$-Gain terhadap penguasaan konsep pada level kognitif C2 Memahami tidak memiliki nilai effect size, pada level kognitif C3 Mengaplikasikan dan C4 Menganalisis memiliki nilai effect size yang diperoleh ada pada kategori sedang. Hal ini menunjukkan bahwa efektivitas penerapan model CUPs untuk meningkatkan penguasaan konsep peserta didik pada materi elastisitas dan hukum Hooke adalah sedang untuk indikator C3 Mengaplikasikan dan C4 Menganalisis. Untuk uji Effect size tiap indikator keterampilan proses sains disajikan pada Tabel 16.

Tabel 16. Hasil Uji Effect Size N-Gain Kelas Eksperimen dan Kelas Kontrol Tiap Indikator KPS.

\begin{tabular}{|c|c|c|c|c|c|c|}
\hline \multirow{2}{*}{ Indikator KPS } & \multicolumn{2}{|c|}{ Eksperimen } & \multicolumn{2}{|c|}{ Kontrol } & \multirow{2}{*}{$\begin{array}{l}\text { Effect Size } \\
\text { (d) }\end{array}$} & \multirow{2}{*}{ Kategori } \\
\hline & $N$-Gain & SD & $N$-Gain & SD & & \\
\hline $\begin{array}{l}\text { 1. Mengidentifi-kasi } \\
\text { variabel }\end{array}$ & 0,21 & 0,36 & 0,15 & 0,59 & 0,12 & Kecil \\
\hline 2. Tabulasi data & 0,04 & 0,27 & 0,21 & 0,63 & $-0,35$ & Tidak ada \\
\hline 3. Menyajikan data & 0,32 & 0,53 & 0,00 & 0,79 & 0,48 & Sedang \\
\hline $\begin{array}{l}\text { 4. Merumuskan } \\
\text { hipotesis }\end{array}$ & 0,70 & 0,40 & 0,46 & 0,75 & 0,40 & Sedang \\
\hline $\begin{array}{l}\text { 5. Menghubung-kan } \\
\text { antar variabel }\end{array}$ & 0,02 & 0,70 & 0,36 & 0,32 & 0,62 & Tidak ada \\
\hline $\begin{array}{l}\text { 6. Menganalisa } \\
\text { penelitian }\end{array}$ & 0,06 & 0,67 & 0,23 & 0,48 & $-0,29$ & Tidak ada \\
\hline 7. Mengolah data & 0,23 & 0,66 & 0,15 & 0,64 & 0,12 & Kecil \\
\hline 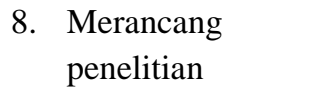 & 0,57 & 0,43 & 0,26 & 0,46 & 0,70 & Sedang \\
\hline $\begin{array}{l}\text { 9. Melaksanakan } \\
\text { eksperimen }\end{array}$ & 0,62 & 0,34 & 0,44 & 0,62 & 0,36 & Sedang \\
\hline
\end{tabular}

Berdasarkan Tabel 16 diperoleh bahwa hasil uji effect size $N$-Gain beragam, dimana pada indikator pertama termasuk kategori kecil, indikator kedua tidak ada, indikator ketiga termasuk kategori sedang, indikator keempat termasuk kategori sedang, indikator kelima tidak ada, indikator keenam tidak ada, indikator ketujuh termasuk kategori kecil, indikator kedelapan termasuk kategori sedang, dan indikator kesembilan termasuk indikator sedang. Hal ini menunjukkan bahwa efektivitas penerapan model CUPs untuk meningkatkan keterampilan proses sains peserta didik pada materi elastisitas dan hukum Hooke adalah relatif beragam, dari yang tidak ada dan paling tinggi adalah kategori sedang.

\section{SIMPULAN}

Berdasarkan penelitian yang telah dilakukan terkait Efektivitas model pembelajaran Conceptual Understanding Procedures (CUPs) terhadap peningkatan penguasaan konsep dan keterampilan proses sains siswa SMA pada materi elastisitas dan hukum Hooke dapat disimpulkan bahwa model pembelajaran CUPs cukup efektif untuk meningkatkan penguasaan konsep tingkat level kognitif C3 mengaplikasikan dan C4 menganalisis, sedangkan untuk C2 memahami memiliki peningkatan yang sama dengan model pembelajaran konvensional atau kurang efektif. Model pembelajaran CUPs juga cukup efektif untuk meningkatkan keterampilan proses sains pada indikatorindikator tertentu yaitu mengidentifikasi variabel, menyajikan data, merumuskan hipotesis, mengolah data, merancang penelitian, dan melaksanakan eksperimen. Namun penerapan model pembelajaran CUPs pada penelitian ini masih belum mampu meningkatkan penguasaan konsep dan keterampilan proses sains siswa untuk mencapai nilai kriteria ketuntasan minimum. Sehingga peneliti menyarankan bagi penelitian selanjutnya untuk memberikan pengetahuan awal terlebih dahulu mengenai indikator- 
indikator keterampilan proses sains sebagai apersepsi sehingga mampu meningkatkan keterampilan proses sains yang akan lebih baik dari sebelumnya.

\section{REFERENSI}

Chen, C. J. et al. 2016. Web Text Reading: “What Satisfy Both Dyslexic and Normal Learners?”, J. Comput. Educ. 3(1), 47-58.

Damayanti, R., dan Ria M. 2015. "Model Pembelajaran Group Investigation untuk Meningkatkan Keterampilan Proses Sains dan Hasil Belajar Siswa Kelas VII B di MTsN Anjir Muara Km. 20". Jurnal Pendidikan Hayati, 1(2), 36-43.

Dwi, I. M., Arif, H., dan Sentot, K. 2013. "Pengaruh Strategi Problem Based Learning Berbasis ICT Terhadap Pemahaman Konsep dan Kemampuan Pemecahan Masalah Fisika”, Jurnal Pendidikan Fisika Indonesia. 9(1), 8-17.

Fraenkel, J. R., Wallen, N. E., Hyun, H. H. 2012. How to Design and Evaluate Research in Education 8th Edition. Boston: McGraw-Hill Higher Education.

Gunawan, G., Setiawan, A., dan Widyantoro, D. H. 2014. "Model Virtual Laboratory Fisika Modern untuk Meningkatkan Keterampilan Generik Sains Calon Guru". Jurnal Pendidikan dan Pembelajaran (JPP). 20(1), 25-32.

Hikmah, N., Baidowi, dan Kurniati, N. 2015. "Penerapan Model Pembelajaran 10 Conceptual Understanding Procedures (Conseptual understanding procedures) untuk Meningkatkan Aktivitas dan Hasil Belajar Matematika Siswa Kelas X SMA Negeri 7 Mataram”. Pijar MIPA. Vol. 9 No, 2, hal. 88

Kanginan, Marthen. 2016. Fisika SMA/MA Kelas XI K13 Revisi. Jakarta: Erlangga.

Permendikbud. 2016. Peraturan Menteri Pendidikan dan Kebudayaan Nomor 21 Tahun 2016 Tentang Standar Isi Pendidikan Dasar dan Menengah.

Sudarmin. 2015. Model Pembelajaran Inovatif Kreatif. Semarang: Unnes Press.

Sugiana, I. N., dkk. 2016. "Pengaruh Model Pembelajaran Generatif Berbantuan Media Laboratorium Virtual Terhadap Penguasaan Konsep Fisika Siswa pada Materi Momentum dan Impuls”. Jurnal Pendidikan Fisika dan Teknologi. 2(2), 61-65.

Tawil, Muh., Liliasari. 2014. Keterampilan-Ketrampilan Sains dan Implementasi dalam Pembelajaran IPA. Makassar: UNM.

Trianto. 2010. Model Pembelajaran Terpadu. Jakarta: Bumi Aksara.

Yang, J., dan Huang, R. 2015. "Development and validation of a scale for evaluating technology-rich classroom environment.”, J. Comput. Educ. 2(2), 145-162.

[OCED] Organisation For Economic Co-Operation And Development. 2016. PISA 2016 Sciences Competencies For Tommorow's World Volume 1. USA: Analysis

Science Education Research Group: Conceptual Understanding Procedure (CUP). 2015. Monash University (Faculty of Education). 31 Januari 2019. <http://monash.edu/science-education/ 2015/resources/conceptual-understanding-procedure/.> 